\title{
Cytotaxonomical Studies in Indian Urginea Steinhill Species
}

\author{
S. R. Yadar and G. B. Dixit \\ Department of Botany, Shivaji University, Kolhapur-416 004 (M. S.) India
}

Accepted December 22, 1989

The genus Urginea Steinhill (Liliaceae) is repersented in India by about nine species (Hooker 1892, Blatter and McCann 1928, Boraiah and Fatima 1970, 1982, Ansari 1981, Hemadri and Swahari 1982). A taxonomic revision of the genus has been made by Deb and Dasgupta (1974, 1981, 1987) and reduced to five species. A survey of literature indicated that $U$. indica and $U$. polyantha are the only taxa studied cytologically while remainings are unexplored from the cytotaxonomic point of view. The present investigation, therefore, reports the comparative karyomorphological analysis in four species of Urginea, viz. $U$. congesta Wight, $U$. razii (Ansari) Deb et Dasgupta, U. polyantha Blatter and McCann and $U$. indica Kunth. It is of particular interest to note that a species $U$. polyphylla Hook. has not been included in present studies because in spite of extensive field trips, authors could not locate it. Its exact natural origin is badly documented, its collector is known to be Heyne (Hooker 1892). After Heyne, there is no report of its occurrence and therefore its presence seems to be doubtful. However, this problem cannot be settled on the basis of the available herbarium specimens alone, relocation of this species in its natural habit is still urgently required.

\section{Materials and methods}

Materials for the present studies were collected from peninsular India. The collected samples (minimum 100 bulbs of each) were grown in the experimental gardens of Botany Department under uniform conditions. The morphological features of the taxa under investigation were critically assessed from fresh materials and voucher specimens have been deposited in the herbarium of the department.

Materials and methods adopted for the karyotype analysis and meiotic studies are the same as reported earlier (Dixit and Yadav 1989). Karyotype symmetry has been analysed using Stebbins' (1958) system of classification based on relative arm-lengths and arm-ratios. $\mathrm{F} \%$ and TF $\%$ were calculated as given by Huziwara 1962, while relative length (TCL \%) and $\mathrm{S} \%$ by applying following formulae:

$$
\begin{aligned}
& \text { Relative length }(\mathrm{TCL} \%)=\frac{\text { Chromosome length }}{\text { Absolute length }} \times 100 \\
& \begin{array}{l}
\text { Relative length of shortest } \\
\text { chromosome }(\mathrm{S} \%)
\end{array}=\frac{\text { Length of shortest chromosome }}{\text { Length of largest chromosome }} \times 100
\end{aligned}
$$

\section{Observations}

General morphological characters of Urginea species under study are tabulated in Table 1, and are showed in Figs. 1-5, and graphically represented in Fig. 6.

All the species of Urginea under investigation are diploids and showing 20 chromosomes in their somatic complements except $U$. indica where B chromosomes are observed (Figs. 7-11). Chromosomes are in general long with subtelocentric centromeres in all the taxa. 


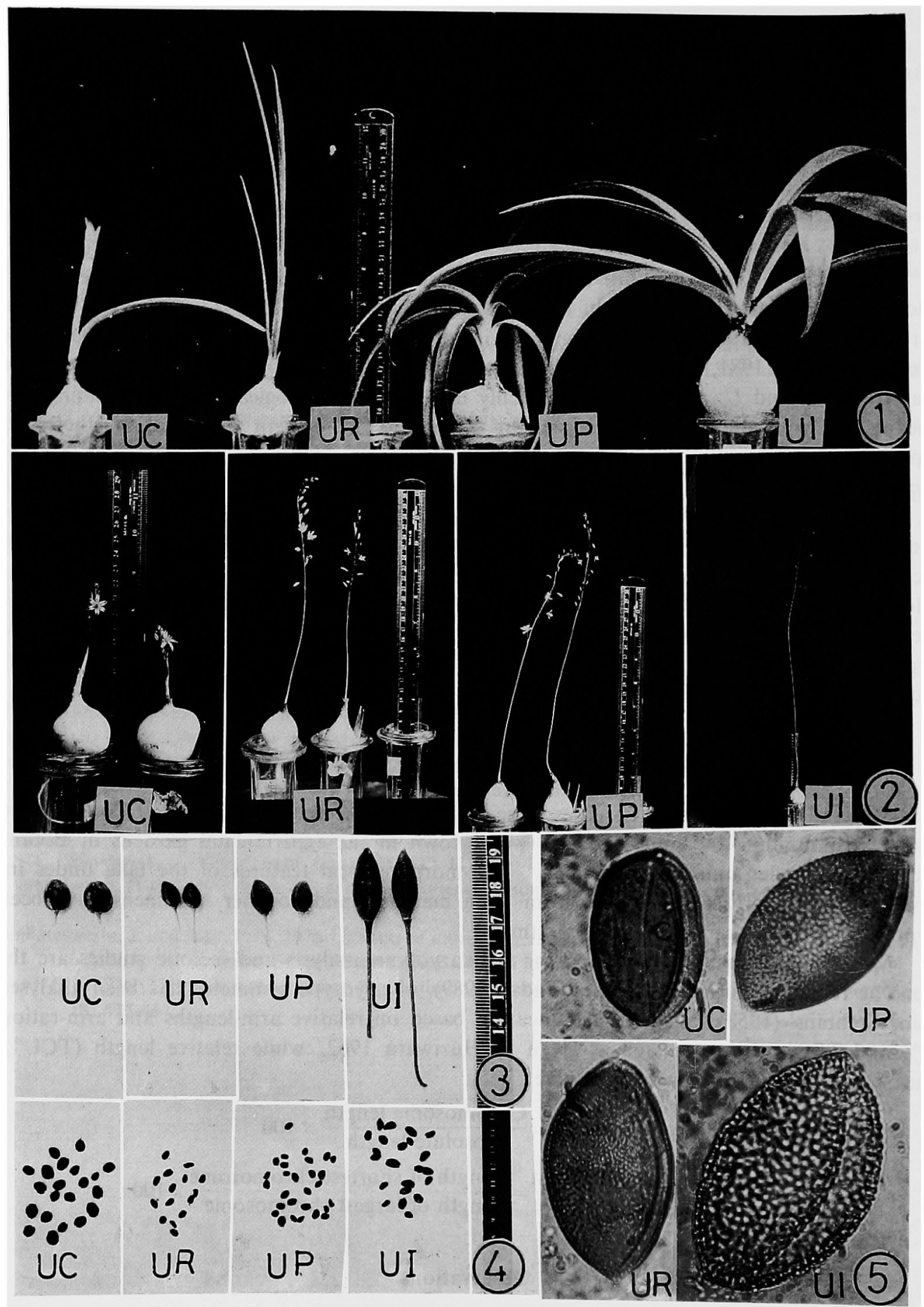

Figs. 1-5. 1, species of Urginea in vegetative phase. 2, species of Urginea in reproductive phase. 3, entire fruits of Urginea species. 4, seeds of Urginea species. 5, pollen grains of Urginea species; $(\times 510$.) UC: $U$. congesta, UR: $U$. razii, UP: $U$. polyantha and UI: $U$. indica. 
With a view to describe the karyotype following categorisation of chromosomes has been made:

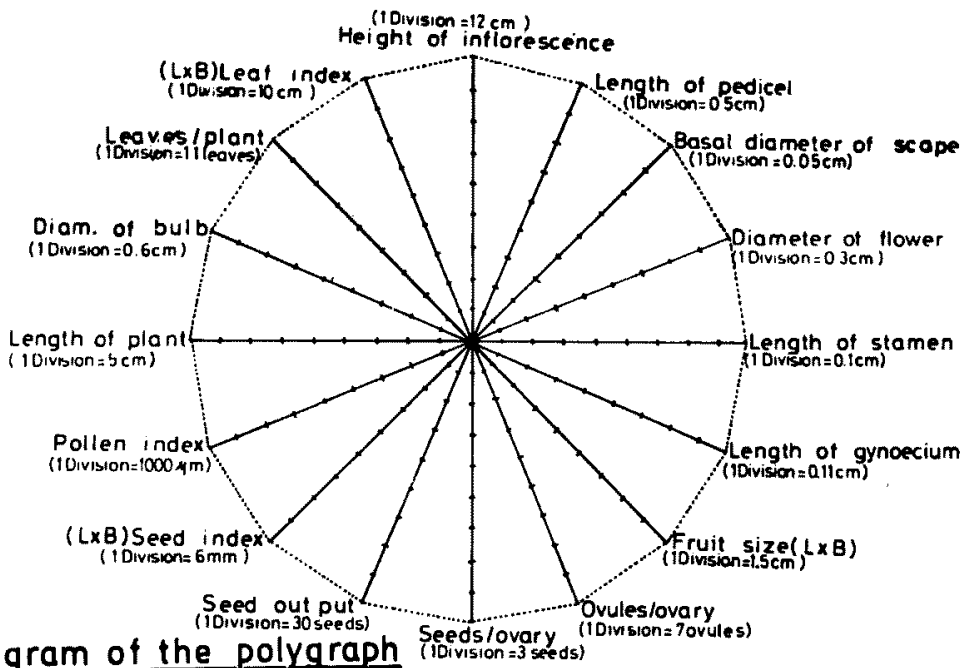

a)Key diagram of the polygraph (iovision 3 seeds)

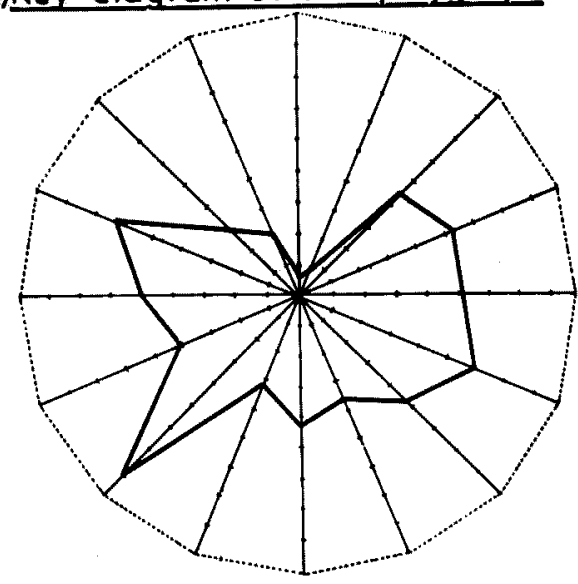

b) Urginea congesta

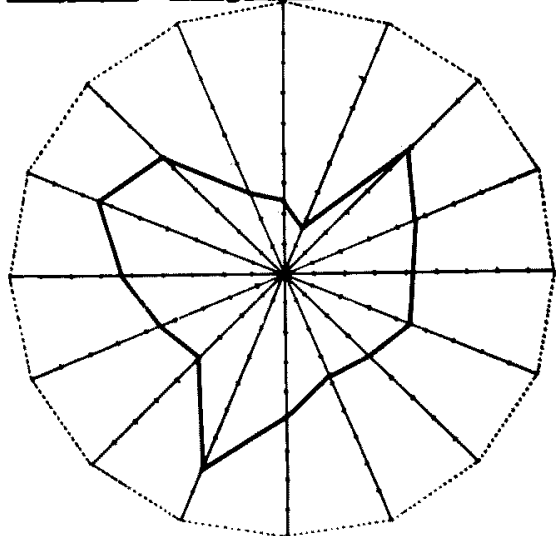

d) U. polyantha

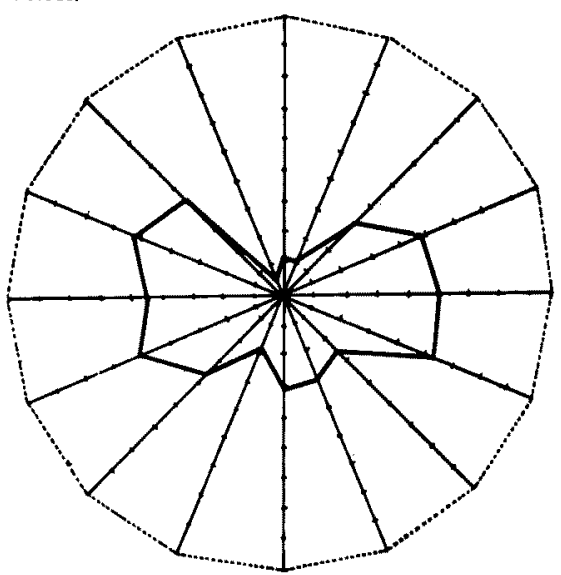

c) U. razil

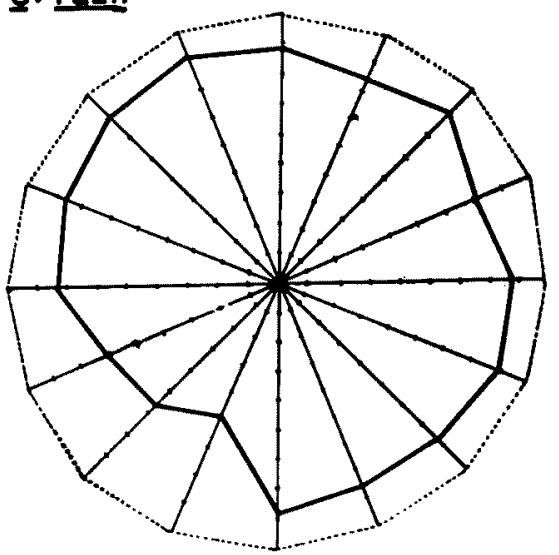

e) U. indica

Fig. 6. Polygraphs of Urginea species. 


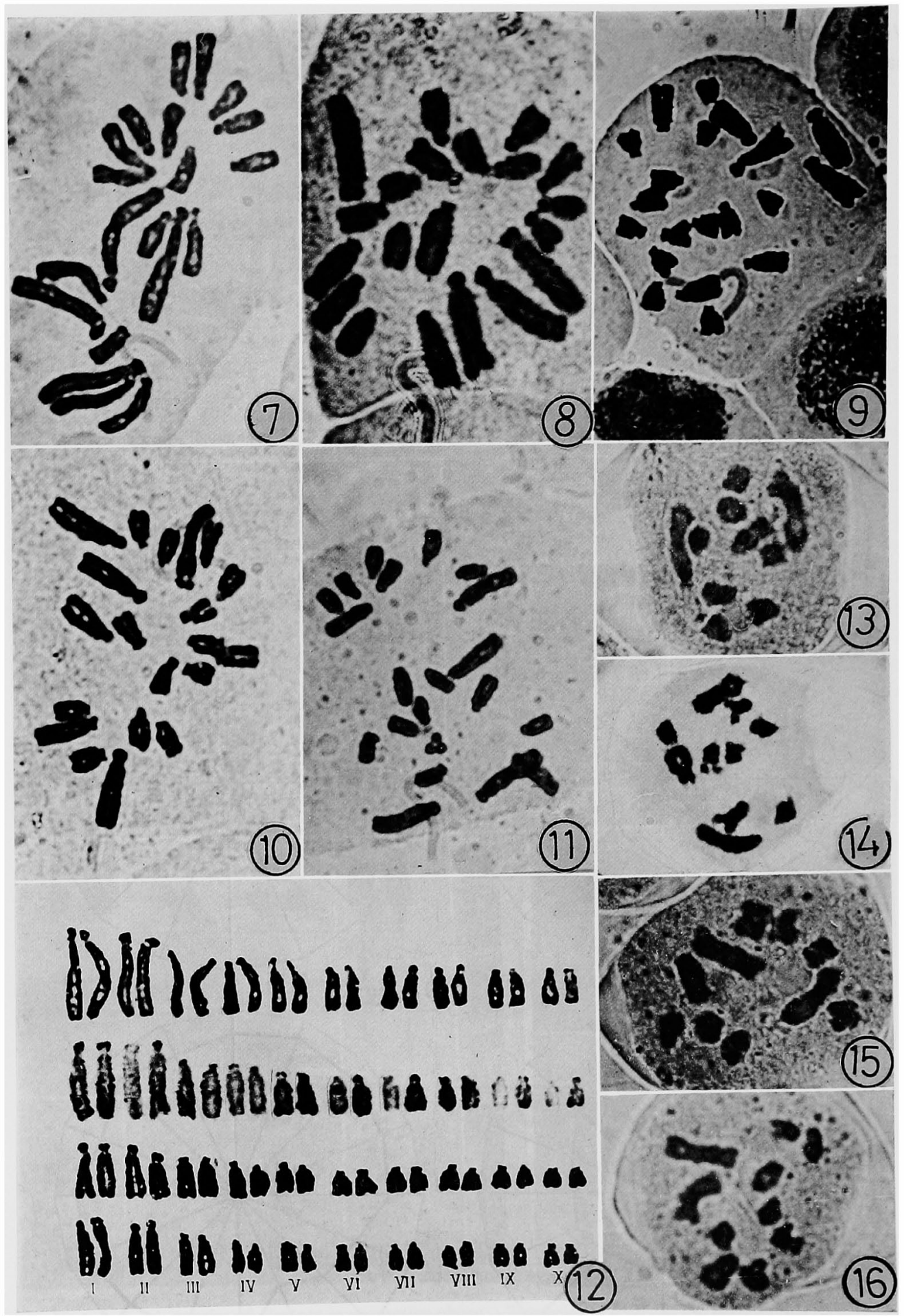

Figs. 7-16. 7, mitotic chromosomes of $U$. congesta showing $2 n=20, \times 1790$. 8 , mitotic chromosomes of $U$. razii showing $2 n=20, \times 1790$. 9, mitotic chromosomes of $U$. polyantha showing $2 \mathrm{n}=$ $20, \times 1790$. 10, mitotic chromosomes of $U$. indica showing $2 \mathrm{n}=20, \times 1790$. 11, mitotic chromosomes of $U$. indica showing $2 n=20+3 \mathrm{~B}, \times 1790$. 12, idiograms of Urginea species: U. congesta, $U$. razii, $U$. polyantha and $U$. indica. 13, diakinesis of $U$. congesta showing 10 bivalents, $\times 930$. 14 , diakinesis of $U$. razii showing 10 bivalents, $\times 930$. 15, diakinesis of $U$. polyantha showing 10 bivalents, $\times 930$. 16 , diakinesis of $U$. indica showing 10 bivalents, $\times 930$. 
Type A: Longest chromosomes $(8.06-7.03 \mu \mathrm{m})$ with constriction in subtelocentric (st) region.

Type B: Long chromosomes $(5.88-6.89 \mu \mathrm{m})$ with constriction in subtelocentric (st) region.

Type C: Medium long chromosomes $(4.04-5.57 \mu \mathrm{m})$ with constriction in subtelocentric (st) region.

Type D: Medium chromosomes (3.02-3.82 $\mu \mathrm{m}$ ) with constriction in subtelocentric (st) region.

Type E: Short chromosomes (2.61-2.98 $\mu \mathrm{m}$ ) with constriction in subtelocentric (st) region.

Details of somatic chromosomes and karyotypic parameters of Urginea species are depicted in Table 2 and idiogrammed in Fig. 12.

The meiosis was found normal in all the taxa under study with 10 bivalents at diakinesis (Figs.13-16). Later stages were also found normal with $92-98 \%$ pollen fertility.

Table 1. Comparative account of morphotaxonomical characters of Indian species of Urginea

\begin{tabular}{|c|c|c|c|c|}
\hline Characters/species & $U$. congesta & U, razii & U. polyantha & U. indica \\
\hline Geographical distribution & $\begin{array}{c}\text { Inland } \\
\text { (Interior area) }\end{array}$ & $\begin{array}{c}\text { Inland } \\
\text { (Interior area) }\end{array}$ & $\begin{array}{c}\text { Inland } \\
\text { (Interior area) }\end{array}$ & $\begin{array}{l}\text { Coastal regions } \\
\text { of the country }\end{array}$ \\
\hline Length of plant (cm) & $25.6 \pm 5.3$ & $21.8 \pm 4.9$ & $26.3 \pm 6.7$ & $37.3 \pm 8.4$ \\
\hline Diameter of bulb $(\mathrm{cm})$ & $3.8 \pm 1.4$ & $3.2 \pm 0.9$ & $3.9 \pm 0.85$ & $4.6 \pm 0.95$ \\
\hline Number of leaves per plant & $3.0 \pm 0.4$ & $5.0 \pm 1.5$ & $6.0 \pm 2.0$ & $9.0 \pm 3.5$ \\
\hline Size of leaf $(L \times B)(\mathrm{cm})$ & $\begin{array}{c}20.5 \pm 5.2 \\
\times 1.03 \pm 0.35\end{array}$ & $\begin{array}{r}15.8 \pm 4.9 \\
\times 0.32 \pm 0.9\end{array}$ & $\begin{array}{r}20.11 \pm 5.6 \\
\times 1.4 \pm 0.6\end{array}$ & $\begin{array}{r}26.9 \pm 7.5 \\
\times 3.1 \pm 0.5\end{array}$ \\
\hline Height of inflorescence $(\mathrm{cm})$ & $6.4 \pm 1.02$ & $15.7 \pm 3.3$ & $29.6 \pm 8.2$ & $95.5 \pm 8.3$ \\
\hline Basal diameter of scape $(\mathrm{cm})$ & $2.3 \pm 0.4$ & $1.64 \pm 0.3$ & $2.8 \pm 0.5$ & $3.9 \pm 0.1$ \\
\hline Pedicel length $(\mathrm{cm})$ & $0.4 \pm 0.2$ & $0.6 \pm 0.2$ & $0.8 \pm 0.1$ & $3.7 \pm 0.8$ \\
\hline Diameter of flower $(\mathrm{cm})$ & $1.6 \pm 0.3$ & $1.5 \pm 0.2$ & $1.4 \pm 0.1$ & $2.1 \pm 0.3$ \\
\hline Blooming period & Day-blooming & Day-blooming & Day-blooming & Night-blooming \\
\hline Anthesis time & 10 a. m. & 10 a. m. & $\begin{array}{l}4 \text { p. m. (previous } \\
\text { day of blooming) }\end{array}$ & 4 p. m. \\
\hline Length of stamen (mm) & $5.2 \pm 0.8$ & $5.2 \pm 0.4$ & $4.2 \pm 0.5$ & $7.7 \pm 0.9$ \\
\hline Length of gynoecium (mm) & $6.7 \pm 0.7$ & $6.09 \pm 0.49$ & $5.07 \pm 0.42$ & $8.86 \pm 0.87$ \\
\hline Ovules per ovary & $25.5 \pm 3.3$ & $20.6 \pm 2.31$ & $26.4 \pm 3.78$ & $52.5 \pm 7.9$ \\
\hline Fruit size $(L \times B)\left(\mathrm{cm}^{2}\right)$ & $7 . \overline{41}$ & 3.82 & 5.97 & 11.46 \\
\hline Seeds per ovary & $12.6 \pm 4.6$ & $9.08 \pm 4.46$ & $14.6 \pm 5.91$ & $23.5 \pm 6.1$ \\
\hline Seed output per plant & 89.3 & 54.5 & 212 & 145.6 \\
\hline Seed index $(\mathrm{L} \times \mathrm{B})\left(\mathrm{mm}^{2}\right)$ & 48.5 & 21.83 & 23.36 & 35.15 \\
\hline Pollen size $(\mathbf{L} \times \mathbf{B})(\mu \mathrm{m})$ & $65 \times 62$ & $73 \times 69$ & $68 \times 64$ & $80 \times 78$ \\
\hline Pollen wall ornamentation & Fine reticulate & Fine reticulate & Reticulate & Coarse Reticulate \\
\hline Chromosome number $(2 n)$ & 20 & 20 & 20 & $20,20+3 \mathrm{~B}$ \\
\hline
\end{tabular}

\section{Discussion}

Indian squill, $U$. indica has extensively been studied cytologically (Raghavan 1935, Naik 1976, Sen 1974, Subramanian 1978, Zha and Sen $1983 \mathrm{a}$, b) and revealed the presence of polyploid, aneuploid series though diploid with $2 n=20$ chromosomes is most common. It is evident from the present investigation that except in $U$. indica all species of Urginea show $2 \mathrm{n}=20$ and $\mathrm{n}=10$ (Figs. 7-11 and 13-16). Thus the first record of chromosome number has been made in $U$, congesta, $U$. razii and haploid number in $U$. polyantha, while confirmation of earlier reports of chromosome number made in $U$. indica and $U$. polyantha.

It is apparent from the present study that all the species represent 'sharp specific differentiations' (Table 1, Figs. 1-6) and asymmetrical karyotype with subterminal primary constrictions in all chromosomes (Table 2, Figs. 7-12). The karyotypes reported for the 
genus all seem to include 2 pairs of long chromosomes, while remaining 8 pairs are more or less gradually decreasing in size from medium to small (Fernandes and Neves 1962, Oyewole 1987). Exception for this is $U$. altissima where 3 submetacentric chromosomes are reported by Nwankiti (1983).

The genus, Urginea, as a whole is well characterised on the basis of morphology and chromosome structure. However, at lower taxonomic levels the few and ill defined morphological traits and considerable degree of genetic and modificational plasticity have prevented a satisfactory systematic differentiation, until recently in $U$. indica. In this context detailed karyotypic analysis of the present study is helpful to ascertain the differences between species at chromosomal level. It is revealed from the Table 2 that karyotypic pattern differs from species to species and thus confer clear species status to the taxa under study.

Differences in absolute chromosome size reflects different amounts of gene duplications either in tandom fashion or through polytene multiplication of chromonemata and also that the species having greater chromatin length were supposed to be primitive whereas species with lesser chromatin length were treated as advanced (Stebbins 1971). It is thus clear from

Table 2. Details of chromosome number and karyotypic parameters in Urginea species

\begin{tabular}{|c|c|c|c|c|c|c|c|c|c|}
\hline Species & $2 n$ & $\mathrm{n}$ & $\begin{array}{c}\text { Total } \\
\text { chromosomal } \\
\text { length }(\mu \mathrm{m}) \text { of } \\
\text { haploid set with } \\
\text { range } \pm \mathrm{S} . \mathrm{E} \text {. }\end{array}$ & $\begin{array}{l}\text { Karyotypic } \\
\text { formula }\end{array}$ & $\begin{array}{c}\text { Range } \\
\text { of } \\
F \%\end{array}$ & $\mathrm{TF} \%$ & $\begin{array}{l}\text { Range } \\
\text { of } \\
\text { TCL } \%\end{array}$ & $\mathrm{~S} \%$ & $\begin{array}{l}\text { Karyotype } \\
\text { symmetry } \\
\text { (Stebbins } \\
\text { notation) }\end{array}$ \\
\hline$U$. congesta & 20 & 10 & $\begin{array}{c}46.68 \\
(8.06-3.11) \\
( \pm 1.57 \pm 0.57)\end{array}$ & $4 A^{s t}+6 C^{s t}+10 D^{s t}$ & $\begin{array}{c}14.38 \\
-19.72\end{array}$ & 16.49 & $\begin{aligned} & 6.66 \\
- & 17.26\end{aligned}$ & 38.58 & $2 b$ \\
\hline$U$. razii & 20 & 10 & $\begin{array}{c}42.52 \\
(7.51-2.75) \\
(+1.61 \pm 0.47)\end{array}$ & $\begin{array}{c}2 A^{s t}+2 B^{s t}+4 C^{s t} \\
+8 D^{s t}+4 E^{s t}\end{array}$ & $\begin{array}{c}16.74 \\
-23.29\end{array}$ & 18.84 & $\begin{array}{c}6.46 \\
-17.66\end{array}$ & 42.24 & $2 b$ \\
\hline$U \cdot$ polyantha & 20 & 10 & $\begin{array}{c}40.72 \\
(7.06-2.01) \\
( \pm 1.13 \pm 0.30)\end{array}$ & $\begin{array}{c}2 A^{s t}+2 B^{s t}+4 C^{s t} \\
+6 D^{s t}+6 E^{s t}\end{array}$ & $\begin{array}{c}16.43 \\
-22.99\end{array}$ & 19.20 & $\begin{array}{r}6.40 \\
-17.33\end{array}$ & 36.97 & $2 b$ \\
\hline$U$. indica & 20 & 10 & $\begin{array}{c}43.33 \\
(7.55-2.73) \\
( \pm 1.06 \pm 0.39)\end{array}$ & $\begin{array}{r}2 A^{s t}+2 B^{s t}+4 C^{s t} \\
+10 D^{s t}+2 E^{s t}\end{array}$ & $\begin{array}{c}13.90 \\
-23.44\end{array}$ & 17.36 & $\begin{array}{c}6.30 \\
-17.42\end{array}$ & 36.15 & $2 b$ \\
\hline
\end{tabular}

the present investigation (Table 2) that amongst 4 species of Urginea, $U$, polyantha is most advanced to others. Wider range of $\mathrm{F} \%$, lower $\mathrm{TF} \%$ and $\mathrm{S} \%$ indicating that specialization of karyotype has taken place in $U$. polyantha followed by $U$. indica, $U$. razii and $U$. congesta. However, close homology is apparent in $U$. indica, $U$. polyantha and $U$. razii while distant relationship with $U$. congesta. The earlier reports on hybridization also supports this view strongly (Dixit and Yadav 1989).

In spite of the same chromosome number in all the 4 species of Urginea under study, the alteration in karyotype formulae (Table 2) at interspecific level is a clear index of the role of structural alterations in evolution of species in this genus. It is also interesting to note that the time of flower opening and closing is peculiar and must have played an important role in speciation. The flowers of $U$. congesta, $U$. razii and $U$. polyantha remain open in day time while those of $U$. indica open during evening hours and close by morning. Thus reproductive isolation through differences in time of blooming of flowers seems to be one of the important factors in speciation of genus Urginea. However, ecogeographical mechanism may be operating in separating them. The wide-spread distribution of $U$. indica and other species of Urginea in 
India leads one to think that the India may be at least a secondary centre of variation for this genus in particular and family in general.

\section{Summary}

Karyotypic analysis of 4 species of Urginea Steinh. from India has been made. All the taxa under study are diploids and showing $2 n=20$ and $n=10$ except $U$. indica where $2 n=$ $20+3 \mathrm{~B}$ is also observed. Asymmetrical karyotype with all subtelocetric chromosomes was found as a characteristic of this genus. It has revealed from the present study that there are sharp specific differences at species level. However, close homology in $U$. indica, $U$. polyantha and $U$. razii while distant relationship of these taxa with $U$. congesta is confirmed. Speciation through structural alterations at chromosomal level and reproductive isolation through differences in time of flower blooming is discussed. Wide distribution and variation in $U$. indica and other species of Urginea in India is considered to be a result of evolution in secondary centre of variation.

\section{Acknowlegment}

The authors are indebted to Prof. B. A. Hegde, Head, Botany Department, Shivaji University, Kolhapur, India, for providing facilities. Our thanks are due to Mr. M. R. Deshmukh for help in the prepaeation of photographs.

\section{References}

Ansari, M. Y. 1981. Drimia razii sp. nov. (Liliaceae) from Maharashtra, India. J. Bombay Nat. Hist. Soc. 78: $572-574$.

Blatter, E. and McCann, C. 1928. Some new species of plants from Western Ghats. J. Bombay Nat. Hist. Soc. 32: 733-773.

Boraiah, G. and Fatima, T. K. 1970. Cytotaxonomy of Urginea govindappae sp. nov. Bull. Bot. Surv. India 12: $129-131$.

— and - 1982. On the genus Urginea Steinh. (Liliaceae) in India. Indian Forest. 108(4): 319.

Deb, D. B. and Dasgupta, S. 1974. Revision of the genus Urginea Steinhill (Liliaceae) in India. Bull. Bot. Surv. India. 16(1-4): 116-124.

— and - 1981. Liliaceae Tribe Scillae, in Fascicles of Flora of India. Bot. Surv. India, Howrah.

- and - 1987. On the identity of three new species of Urginea (Liliaceae). J. Bombay Nat. Hist. Soc. 84: 409-412.

Dixit, G. B. and Yadav, S. R. 1989. Cytotaxonomical and genetical studies in Urginea Steinh. species from India. Cytologia 54: 715-721.

Fernandes, A. and Neves, J. B. 1962. Sur la caryologie de quelques monocotylédones Africaines. Compt. Rend, 4e Réunion Pléniere de L'AETFAT: 439-464.

Hemadri, K. and Swahari, S. 1982. Urginea nagarjunae Hemadri et Swahari - a new species of Liliaceae from India (a new plant discovery). Ancient Sc. Life 2: 105-110.

Hooker, J. D. 1892. Liliaceae. Flora of British India, London.

Huziwara, Y. 1962. Karyotype analysis in some genera of Compositae VIII. Further studies on the chromosome of Aster. Amer. J. Bot. 49: 116-119.

Naik, V. N. 1976. Cytotaxonomic studies in two species of Urginea Steinh. from India. J. Ind. Bot. Soc. 55: $60-64$.

Nwankiti, O.C. 1983. Cytotaxonomic survey of some tropical ornamental species. 2. Urginea altissima. Indian J. Genet. 43: 418-420.

Oyewole, S. O. 1987. Cytotaxonomic studies in the genus Urginea Steinh. in West Africa III. The case of Urginea indica Kunth, in Nigeria. Ann. No. Bot. Gard. 74: 131-136.

Raghavan, T. S. 1935. Observations on the somatic chromosomes of Urginea indica Kunth. J. Ind. Bot. Soc. 14: 151-158.

Sen, S. 1974. Nature and behaviour of B-chromosomes in Allium stracheyii and Urginea indica Kunth. Cy- 
tologia $39: 245-251$.

Stebbins, G. L. 1958. Longevity, habitat and release of genetic variability in higher plants. Cold Spr. Harb. Sym. Quant. Biol. 23: 365-378.

- 1971. Chromosomal Evolution in Higher Plants. Edward Arnold publ. Ltd., London, $49-113$.

Subramanian, D. 1978. Cytogenetical studies in Urginea indica (Roxb.) Kunth. J. Ind. Bot. Soc. 57: 211218.

Zha, S. and Sen, S. 1983a. Chromosome study of diploid Indian squill. Cytologia 48: 79-86.

- and - 1983b. Chromosome study of polyploid Indian squill, Urginea indica Kunth. Cytologia 48: 407418. 